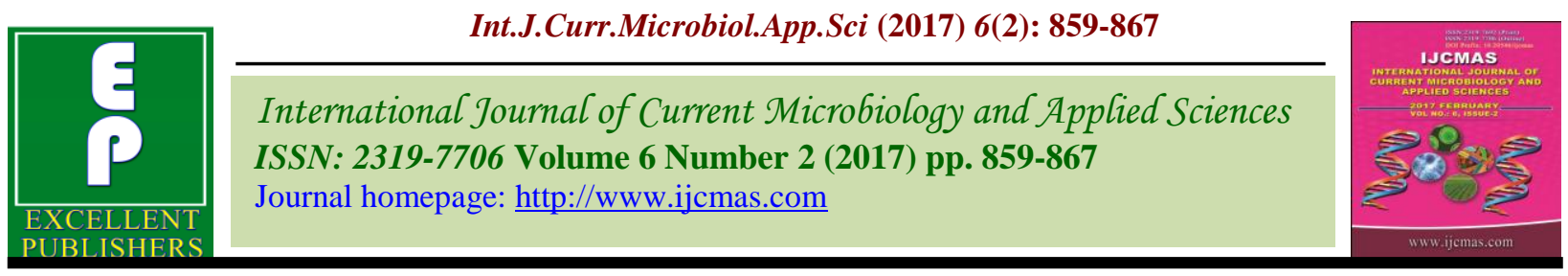

Original Research Article

http://dx.doi.org/10.20546/ijcmas.2017.602.096

\title{
Development and Evaluation of Integrated Pest Management Strategy against Sucking Pest Complex of Cocoa, Theobroma cacao $\mathrm{L}$.
}

\author{
S. Srinivasnaik ${ }^{1}$, M. Suganthy ${ }^{1}$, S. Mohan Kumar ${ }^{2}$ and V. Jegadeeswari ${ }^{3}$ \\ ${ }^{1}$ Department of Agricultural Entomology, Centre for Plant Protection Studies, Tamil Nadu \\ Agricultural University, Coimbatore, Tamil Nadu, India - 641003 \\ ${ }^{2}$ Centre for Plant Molecular Biology and Biotechnology (CPMB \& B), Tamil Nadu Agricultural \\ University, Coimbatore, Tamil Nadu, India - 641003 \\ ${ }^{3}$ Department of Spices and Plantation Crops, Tamil Nadu Agricultural University, Coimbatore, \\ Tamil Nadu, India - 641003 \\ *Corresponding author:
}

\section{A B S T R A C T}

A field experiment was conducted in a farmer's holding at Sethumadai, Pollachi, Tamil Nadu to develop integrated pest management strategy against sucking pest complex of cocoa including tea mosquito bugs, mealybugs and aphids during 2014-2015 using randomised block design with three treatments (IPM module, farmer's practice and

Keywords

IPM,

sucking pests,

cocoa,

natural enemies, yield.

Article Info

Accepted:

18 January 2017

Available Online:

10 February 2017 control) and replicated seven times in an area of $10,000 \mathrm{~m}^{2}$. The experimental results revealed that the IPM strategy was significantly superior to farmer's practice and untreated control in reducing the population of aphids (Toxoptera aurantii), mealybugs (Paracoccus marginatus and Planococcus citri) and tea mosquito bugs (Helopeltis bradyi and $H$. antonii) with the mean per cent reduction of $91.1,94.0$ and 84.4 over control, respectively. Number of Cryptolaemus montrouzieri, Spalgis epeus, syrphids and spiders recorded at 21 days after treatment were 5.7, 4.1, 2.1 and 1.7 per tree in IPM strategy as against 1.2, 0.5, 0 and 0.8 per tree in farmer's practice, respectively. Regarding yield parameters, the maximum number of harvestable pods $(28.6)$, maximum pod length $(18.5 \mathrm{~cm})$, maximum pod girth $(26.6 \mathrm{~cm})$, maximum pod weight $(588.8 \mathrm{~g})$, highest number of beans (37.9), highest wet bean weight per pod $(126.0 \mathrm{~g})$, maximum dry bean weight per pod $(39.4 \mathrm{~g})$ and the highest dry bean yield of 984 g per tree per season were recorded in IPM plot than the farmer's and untreated control. Based on the results, the IPM strategy was adjudged as the most effective treatment for the protection of cocoa against attack by sucking pests. It is concluded from the results that adoption of the IPM strategy is recommended not only to increase the productivity of cocoa, but also to conserve the natural enemies and pollinators in the cocoa ecosystem.

\section{Introduction}

Cocoa (Theobroma cacao L.) (Family: Malvaceae) is one of the greatest treasurers ever discovered by man. It is the only source of chocolate and is a rich source of sensory pleasure and energy, adored by almost everyone. It is the third important beverage crop next to coffee and tea, and is also third highest traded commodity in the world (Gopikrishna, 2014). It is one of the world's most valuable crops playing an important role in socio economic life of more than 5 million households and affecting 25 million in poor rural areas in the major cocoa growing countries viz., Cameron, Ivory Coast, Ghana, 
Nigeria (Africa); Brazil, Ecuador (America); Indonesia, Malaysia and other Asian countries (Prasannakumari et al., 2012). Cocoa is cultivated worldwide over an area of 8.2 million hectares in 58 countries and the top five producers account for over 70 per cent of the total production (Prasannakumari et al., 2012). Globally 43.55 lakh metric tonnes of cocoa produced in 2014 (Gopikrishna, 2014). In India, cocoa cultivation is largely confined to southern states viz., Kerala, Karnataka, Tamil Nadu and Andhra Pradesh. India ranks eighteenth among the countries cultivating cocoa having an area of 71,000 hectares with a production of 15,000 metric tonnes. Kerala is the leading cocoa producing state in India with a share of 41.72 per cent followed by Andhra Pradesh (37.08 per cent), Karnataka (13.90 per cent) and Tamil Nadu (7.28 per cent). On an average, India contributes 0.34 per cent to the world cocoa production (Indian Horticulture Database, 2014).

Pests and diseases have largely contributed to declining productivity of cocoa in India. Cocoa as a perennial tree crop is ravaged by many insect pests including sucking and borers right from the seedling stage to the fruit harvesting. The sucking pest complex includes tea mosquito bugs (Helopetis antonii, $H$. bradyi), mealybugs (Planococcus citri and (Paracoccus marginatus) aphids (Toxoptera aurantii), etc. and the borers include pod and bark borers attacking in India (Prasannakumari et al., 2012). About 25-30 per cent yield loss in cocoa had been attributed to cocoa mirid (Sahlbergella singularis) while, 17 per cent is lost by cocoa pod borer (Characoma strictigrapta) (Uwagboe et al., 2012). These losses lead to reduced income, poverty, food insecurity and loss of biodiversity.

In India, the sucking pests of cocoa are managed by spraying systemic insecticides. Integrated pest management system focuses on long-term prevention of pests and their damage. The success of IPM under such conditions is often measured in financial terms, such as savings on pesticides and subsequent reductions in costs to the environment and other externalities. The advantage of IPM in cocoa, as with other crops is not only the reduction in the use of chemical pesticides, but can offer an economic incentive to growers by increase in quality that can be achieved (Wandji et al., 2006; Gockowski and Sonwa, 2008). In India, the research on development of IPM strategies against economically important insect pests of cocoa is limited. There is an urgent need to develop suitable IPM strategy for this plantation crop, which is gaining importance among the farming community. Keeping these gaps in mind, the study sought to develop IPM strategy against sucking pest complex of cocoa.

\section{Materials and Methods}

A field experiment was conducted in 16 years old forastero type plantations in the farmer's holding at Sethumadai, Pollachi taluk of Coimbatore district in Tamil Nadu during 2014-2015 against sucking pest complex of cocoa (aphids, mealybugs and tea mosquito bugs) as they were found to be predominant pests infesting cocoa with the following 3 treatments and 7 replications in a randomized block design in $10,000 \mathrm{~m}^{2}$ area of cocoa plantation. To check the effectiveness of different treatments and to avoid the drift of insecticide, the plots were separated by a distance of $100 \mathrm{~m}$.

$\mathrm{T}_{1}$ - IPM strategy (Proper pruning and clean cultivation; erection of yellow sticky light traps at 10 per ha; filed release of $C$. montrouzieri at 10 beetles per tree coinciding with the population build up of Planococcus lilacinus and $P$. citri; field release of Acerophagus papayae at 100 per hamlet coinciding with the population build up of 
Paracoccus marginatus; foliar application of Beauveria bassiana $\left(2 \times 10^{8} \mathrm{cfu} / \mathrm{ml}\right)$ at $5 \mathrm{~kg}$ per ha coinciding with the population build up of tea mosquito bugs; foliar application of azadirachtin $10,000 \mathrm{ppm}$ at $500 \mathrm{ml}$ per ha coinciding with peak flowering (to conserve pollinators); foliar application of thiacloprid $21.7 \% \mathrm{SC}$ at $750 \mathrm{ml}$ per ha during pod formation stage).

$\mathrm{T}_{2}$ - Farmer's practice (six sprays of thiacloprid $21.7 \%$ SC at 15 days interval)

$\mathrm{T}_{3^{-}}$Untreated control

Severity of sucking pests was observed from January to April, 2015. Hence, the treatments were imposed at 15 days interval from first fortnight of January to second fortnight of April, 2015. Observations were made on 10 randomly selected trees per treatment. Observations on the population of aphids were made on top three leaves per tree and for mealybugs and tea mosquito bugs, population counts were made on three randomly selected pods per tree. Apart from pre-treatment count, post treatment counts were taken on 1, 3, 5, 7, 14 and 21 days after imposing last spray. Per cent pod damage by tea mosquito bugs, population of natural enemies, pod (number of harvestable pods, pod length $(\mathrm{cm})$, pod girth (cm), pod weight $(\mathrm{g})$ ) and bean yield parameters (number of beans per pod, wet bean weight per pod $(\mathrm{g})$, dry bean weight per pod $(\mathrm{g})$, dry bean yield per tree per season $(\mathrm{g})$ ) were recorded. The parameters were measured using weighing balance to measure the weight, thread and scale for girth and length and the number of beans and harvestable pods were counted at 21 days after imposing the last treatment of foliar application of thiacloprid $21.7 \%$ SC. Per cent pod damage was calculated using the formula of Kumar and Krishnanaik (2002): Pod damage $(\%)=$ (Number of infested pods/Total number of pods) X 100.
The data obtained from the field experiments from various treatments against sucking pests were analyzed using AGRES ver. (7.01), Pascal International Solutions. The data in numbers were subjected to square root transformation and the data in percentage were subjected to arcsine transformation before analysis and mean values were separated by LSD (Gomez and Gomez, 1984).

\section{Results and Discussion}

\section{Efficacy of IPM strategy against sucking pest complex}

\section{Aphids, Toxoptera aurantii}

Results revealed that at 1,3 and 5 days after treatment (DAT), the number of aphids recorded in the IPM plot were $0.6,0.3$ and 0 per top three leaves per tree, while, it was 0.7 , 0.4 and 0.1 aphids in the farmer's practice, respectively. Per cent reduction in aphid population over the untreated control was 99.6, 99.9 and 100 at 1,3 and 5 DAT, respectively in IPM plot, whereas, it was 99.5, 99.8 and 99.9 per cent in the farmer's practice. Statistical analysis revealed that there was no significant difference between IPM treatment and the farmer's practice in reducing the aphid population up to 5 DAT (Table 1).

At 7, 14 and 21 DAT, the number of aphids was recorded to be $8.6,28$ and 33.1 per tree in the IPM plot, while, it was 11.9, 35.3 and 59.1 , respectively in the farmer's practice. Per cent reduction in aphid population over the untreated control was 93.2, 79.5 and 74.1 at 7, 14 and 21 DAT, respectively in IPM plot, whereas, it was $90.6,74.2$ and 54 per cent in the farmer's practice. IPM treatment was found to be significantly superior to other treatments in reducing the aphid population at 7, 14 and 21 DAT (Table 1). 
Mealybug, Planococcus citri and Paracoccus marginatus

Regarding mealybugs At 1, 3 and 5 DAT, there is no significant difference between the IPM and the farmers practice in controlling mealybugs (Table 2). At 7, 14 and 21 DAT, the number of mealybugs was recorded to be $(10.6,11.9),(28.5,25.6)$ and $(35.2,35.3)$ in the IPM plot, while, it was $(15.9,27.7)(39.4$, $36.1)$ and $(50.9,58.3)$ in the farmer's practice. Per cent reduction in mealybug population over control was $(96,94.4)(89.9,88.4)$ and (87.2, 84.3) at 7, 14 and 21 DAT, respectively in IPM plot, while, it was $(94.1,86.9),(86$, 83.6) and $(81.5,74.1)$ per cent in farmer's practice. IPM treatment was found to be significantly superior to other two treatments in reducing the mealybug population even at 7, 14 and 21 DAT (Tables 2 and 3).

\section{Tea mosquito bugs}

Results revealed that at 1, 3 and 5 DAT, the number of tea mosquito bugs was recorded to be 1.3, 0 and 0 per three pods per tree in the IPM plot, while, it was 3, 1.4 and 0.9 in the farmer's practice, respectively. Per cent reduction in tea mosquito bug population over control was $88.5,100$ and 100 at 1,3 and 5 DAT, respectively in IPM plot, while, it was 76.9, 86.8 and 92.4 per cent in farmer's practice (Table 4).

At 7, 14 and 21 DAT, the number of tea mosquito bugs recorded was $1.3,3$ and 4.1 in the IPM plot, while, it was 2.6, 5.9 and 8.9 in the farmer's practice. Per cent reduction in tea mosquito bug population over control was 86.2, 70 and 61.9 at 7, 14 and 21 DAT, respectively in IPM plot, while, it was 72.3, 41.4 and 18.4 per cent in farmer's practice. Statistical analysis revealed that the IPM strategy was found to be highly effective and significantly superior to the farmer's practice in reducing the tea mosquito bug population. The damage by tea mosquito bug was recorded to be 10.5, 26.6 and 68.3 per cent in IPM plot, farmer's practice and untreated control, respectively. Per cent reduction in the damage was 84.6 and 61.1 in IPM plot and farmer's practice, respectively, over the untreated control (Table 4).

Ayenor et al., (2007) observed per cent mortality of cocoa capsids in cages to be 79 to 88 per cent in the field after 48 hours of treatment with 20 per cent aqueous neem seed extract. Dutta et al., (2013) also reported that aqueous extract of neem seed kernel at 5 per cent concentration was found to be effective against tea mosquito bug, $H$. theivora in the laboratory conditions in terms of antifeedant activity, hatching percentage, oviposition period and nymphal duration.

\section{Effect of IPM strategy on natural enemies}

Results revealed that at 21 DAT, number of Cryptolaemus montrouzieri was recorded to be 5.7, 1.2 and 11.3; Spalgis epeus was recorded to be 4.1, 0.5 and 9.6; syrphid grubs was found to be 2.1, 0 and 6.3; The number of spiders was recorded to be 1.7, 0.8 and 5 per tree in IPM plot, farmer's practice and untreated control, respectively. Statistical analysis revealed that among all the treatments, untreated control was significantly superior in conserving natural enemy population followed by IPM treatment (Table 5). Sakthivel and Qadri (2010) reported that the population of coccinellid beetles was drastically reduced in the plots treated with dichlorovos (88.63 per cent), followed by phosalone (78.6 per cent), dimethoate (72.2 per cent) and metasystox (69 per cent) at one day after treatment. Pungam oil (29.7 per cent) and neem oil (35.2 per cent) were found to be safe to the beneficial beetles. The population of predators regained activity significantly at 5 DAS in the plots treated with pungam oil and neem oil. 
Table.1 Efficacy of different pest management practices against Toxoptera aurantii infesting cocoa during 2014-2015

\begin{tabular}{|c|c|c|c|c|c|c|c|c|c|c|c|c|c|c|c|c|}
\hline \multirow[b]{2}{*}{ S. No } & \multirow[b]{2}{*}{ Treatments } & \multicolumn{8}{|c|}{ Number of aphids / top 3 leaves / tree * } & \multicolumn{7}{|c|}{ Per cent reduction over control } \\
\hline & & PTC & $\begin{array}{c}1 \\
\text { DAT }\end{array}$ & $\begin{array}{c}3 \\
\text { DAT }\end{array}$ & $\begin{array}{c}5 \\
\text { DAT }\end{array}$ & $\begin{array}{c}7 \\
\text { DAT }\end{array}$ & $\begin{array}{c}14 \\
\text { DAT }\end{array}$ & $\begin{array}{c}21 \\
\text { DAT }\end{array}$ & Mean & $\begin{array}{c}1 \\
\text { DAT }\end{array}$ & $\begin{array}{c}3 \\
\text { DAT }\end{array}$ & $\begin{array}{c}5 \\
\text { DAT }\end{array}$ & $\begin{array}{c}7 \\
\text { DAT }\end{array}$ & $\begin{array}{c}14 \\
\text { DAT }\end{array}$ & $\begin{array}{c}21 \\
\text { DAT }\end{array}$ & Mean \\
\hline 1 & $\begin{array}{l}\text { IPM } \\
\text { module }\end{array}$ & 110.0 & $\begin{array}{c}0.6^{\mathrm{a}} \\
(1.0)\end{array}$ & $\begin{array}{c}0.3^{\mathrm{a}} \\
(0.9)\end{array}$ & $\begin{array}{l}0.0^{\mathrm{a}} \\
(0.7)\end{array}$ & $\begin{array}{l}8.6^{\mathrm{a}} \\
(3.0)\end{array}$ & $\begin{array}{l}28.0^{\mathrm{a}} \\
(5.3)\end{array}$ & $\begin{array}{l}33.1^{\mathrm{a}} \\
(5.8)\end{array}$ & 11.8 & 99.6 & 99.9 & 100.0 & 93.2 & 79.5 & 74.1 & 91.1 \\
\hline 2 & $\begin{array}{l}\text { Farmer's } \\
\text { practice }\end{array}$ & 105.5 & $\begin{array}{c}0.7^{\mathrm{a}} \\
(1.1)\end{array}$ & $\begin{array}{c}0.4^{\mathrm{a}} \\
(1.0)\end{array}$ & $\begin{array}{c}0.1^{\mathrm{a}} \\
(0.8)\end{array}$ & $\begin{array}{l}11.9^{b} \\
(3.5)\end{array}$ & $\begin{array}{l}35.3^{b} \\
(6.0)\end{array}$ & $\begin{array}{l}59.1^{b} \\
(7.7)\end{array}$ & 17.9 & 99.5 & 99.8 & 99.9 & 90.6 & 74.2 & 54.0 & 86.3 \\
\hline 3 & $\begin{array}{l}\text { Untreated } \\
\text { control }\end{array}$ & 145.5 & $\begin{array}{l}138.2^{b} \\
(11.8)\end{array}$ & $\begin{array}{l}146.0^{b} \\
(12.1)\end{array}$ & $\begin{array}{l}125.7^{b} \\
(11.2)\end{array}$ & $\begin{array}{l}126.4^{c} \\
(11.3)\end{array}$ & $\begin{array}{l}136.9^{c} \\
(11.7)\end{array}$ & $\begin{array}{l}128.4^{\mathrm{c}} \\
(11.4)\end{array}$ & 133.6 & - & - & - & - & - & - & - \\
\hline & $\begin{array}{l}\mathrm{CD} \\
(\mathrm{P}=0.05)\end{array}$ & NS & 0.17 & 0.13 & 0.08 & 2.12 & 1.94 & 2.61 & - & - & - & - & - & - & - & - \\
\hline
\end{tabular}

PTC - Pre treatment count; DAT - Days after treatment; *Mean of 7 replications; NS-Non significant

In a column, means followed by common letter(s) are not significantly different by LSD; Figures in parenthesis are square root transformed values

Table.2 Efficacy of different pest management practices against Planococcus citri infesting cocoa during 2014-2015

\begin{tabular}{|c|c|c|c|c|c|c|c|c|c|c|c|c|c|c|c|c|}
\hline \multirow[b]{2}{*}{ S. No } & \multirow[b]{2}{*}{$\begin{array}{l}\text { Treatment } \\
\text { s }\end{array}$} & \multicolumn{8}{|c|}{ Number of Planococcus citri / 3 pods / tree * } & \multicolumn{7}{|c|}{ Per cent reduction over control } \\
\hline & & PTC & $\begin{array}{c}1 \\
\text { DAT }\end{array}$ & $\begin{array}{c}\mathbf{3} \\
\text { DAT }\end{array}$ & $\begin{array}{c}5 \\
\text { DAT }\end{array}$ & $\begin{array}{c}7 \\
\text { DAT }\end{array}$ & $\begin{array}{c}14 \\
\text { DAT }\end{array}$ & $\begin{array}{c}21 \\
\text { DAT }\end{array}$ & Mean & $\begin{array}{c}1 \\
\text { DAT }\end{array}$ & $\begin{array}{c}\text { 3 } \\
\text { DAT }\end{array}$ & $\begin{array}{c}5 \\
\text { DAT }\end{array}$ & $\begin{array}{c}7 \\
\text { DAT }\end{array}$ & $\begin{array}{c}14 \\
\text { DAT }\end{array}$ & $\begin{array}{c}21 \\
\text { DAT }\end{array}$ & $\begin{array}{c}\text { Mea } \\
\text { n }\end{array}$ \\
\hline 1 & \begin{tabular}{|l|} 
IPM \\
module
\end{tabular} & 262.6 & $\begin{array}{l}10.3^{\mathrm{a}} \\
(3.3)\end{array}$ & $\begin{array}{l}3.9^{\mathrm{a}} \\
(2.1)\end{array}$ & $\begin{array}{l}0.0^{\mathrm{a}} \\
(0.7)\end{array}$ & $\begin{array}{l}10.6^{\mathrm{a}} \\
(3.3)\end{array}$ & $\begin{array}{l}28.5^{\mathrm{a}} \\
(5.4)\end{array}$ & $\begin{array}{l}35.2^{\mathrm{a}} \\
(6.0)\end{array}$ & 14.7 & 96.4 & 98.5 & 100.0 & 96.0 & 89.9 & 87.2 & 94.7 \\
\hline 2 & $\begin{array}{l}\text { Farmer's } \\
\text { practice }\end{array}$ & 249.5 & $\begin{array}{l}11.0^{\mathrm{a}} \\
(3.4)\end{array}$ & $\begin{array}{l}4.4^{\mathrm{a}} \\
(2.2)\end{array}$ & $\begin{array}{l}0.0^{\mathrm{a}} \\
(0.7)\end{array}$ & $\begin{array}{l}15.9^{b} \\
(4.0)\end{array}$ & $\begin{array}{l}39.4^{b} \\
(6.3)\end{array}$ & $\begin{array}{l}50.9^{b} \\
(7.2)\end{array}$ & 20.3 & 96.1 & 98.3 & 100.0 & 94.1 & 86.0 & 81.5 & 92.7 \\
\hline 3 & $\begin{array}{l}\text { Untreated } \\
\text { control }\end{array}$ & 297.0 & $\begin{array}{l}282.3^{b} \\
(16.9)\end{array}$ & $\begin{array}{l}261.7^{b} \\
(16.2)\end{array}$ & $\begin{array}{l}272.1^{b} \\
(16.5)\end{array}$ & $\begin{array}{l}266.3^{c} \\
(16.3)\end{array}$ & $\begin{array}{l}281.1^{\mathrm{c}} \\
(16.8)\end{array}$ & $\begin{array}{l}275.3^{\mathrm{c}} \\
(16.6)\end{array}$ & 273.1 & - & - & - & - & - & - & - \\
\hline & S. Ed & - & 2.70 & 1.98 & 0.03 & 1.11 & 1.77 & 1.25 & - & - & - & - & - & - & - & - \\
\hline & $\mathrm{CD}(\mathrm{P}=0.05)$ & $\mathrm{NS}$ & 5.90 & 4.33 & 0.08 & 2.42 & 3.85 & 2.74 & - & - & - & - & - & - & - & - \\
\hline
\end{tabular}

PTC - Pre treatment count; DAT- Days after treatment; *Mean of 7 replications

In a column, means followed by common letter(s) are not significantly different by LSD; Figures in parenthesis are square root transformed values 
Table.3 Efficacy of different pest management practices against Paracoccus marginatus infesting cocoa during 2014-2015

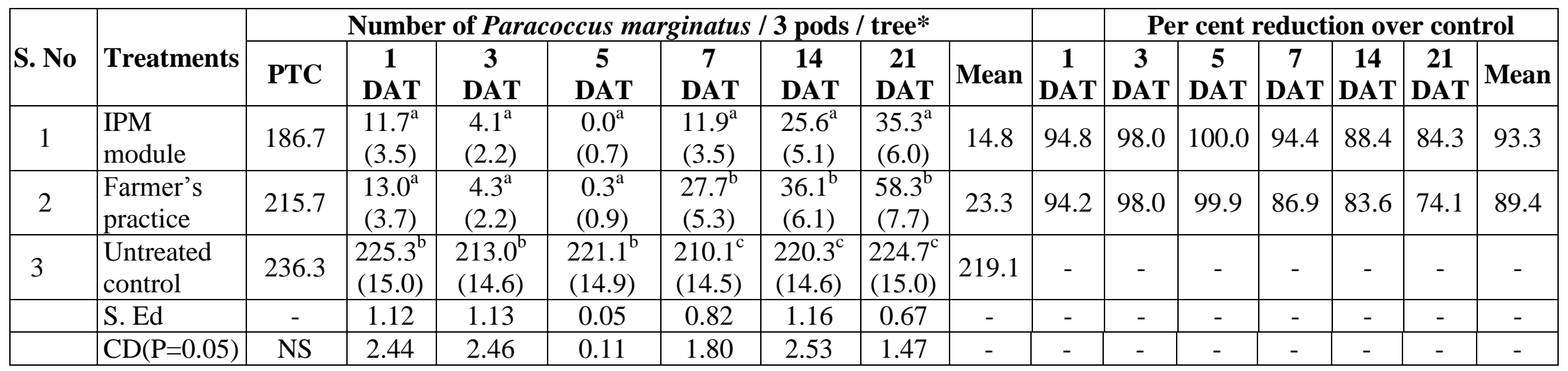

PTC - Pre treatment count; DAT - Days after treatment; *Mean of 7 replications; NS-Non significant

In a column, means followed by common letter(s) are not significantly different by LSD; Figures in parenthesis are square root transformed values

Table.4 Efficacy of different pest management practices against tea mosquito bugs infesting cocoa during 2014-2015

\begin{tabular}{|c|c|c|c|c|c|c|c|c|c|c|c|c|c|c|c|c|c|c|}
\hline \multirow[b]{2}{*}{ No } & \multirow[b]{2}{*}{ Treatments } & \multicolumn{9}{|c|}{ Number of tea mosquito bugs / 3 pods / tree * } & \multicolumn{8}{|c|}{ Per cent reduction over control } \\
\hline & & PTC & $\begin{array}{c}1 \\
\text { DAT }\end{array}$ & $\begin{array}{c}3 \\
\text { DAT }\end{array}$ & $\begin{array}{c}5 \\
\text { DAT }\end{array}$ & $\begin{array}{c}7 \\
\text { DAT }\end{array}$ & $\begin{array}{c}14 \\
\text { DAT }\end{array}$ & $\begin{array}{c}21 \\
\text { DAT }\end{array}$ & Mean & $\begin{array}{c}\text { Damage } \\
(\%)\end{array}$ & $\begin{array}{c}\mathbf{1} \\
\mathbf{D A} \\
\mathbf{T}\end{array}$ & $\begin{array}{c}3 \\
\text { DAT }\end{array}$ & $\begin{array}{c}5 \\
\text { DAT }\end{array}$ & \begin{tabular}{|c|}
7 \\
DA \\
T
\end{tabular} & \begin{tabular}{|c|}
14 \\
DA \\
T
\end{tabular} & \begin{tabular}{|c|}
21 \\
DA \\
T
\end{tabular} & Mean & $\begin{array}{c}\text { Damage } \\
(\%)\end{array}$ \\
\hline & $\begin{array}{l}\text { IPM } \\
\text { module }\end{array}$ & 8.6 & $\begin{array}{l}1.3^{\mathrm{a}} \\
(1.3)\end{array}$ & $\begin{array}{l}0.0^{\mathrm{a}} \\
(0.7)\end{array}$ & $\begin{array}{l}0.0^{\mathrm{a}} \\
(0.7)\end{array}$ & $\begin{array}{l}1.3^{\mathrm{a}} \\
(1.3)\end{array}$ & $\begin{array}{l}3.0^{\mathrm{a}} \\
(1.9)\end{array}$ & $\begin{array}{l}4.1^{\mathrm{a}} \\
(2.2)\end{array}$ & 1.6 & 10.5 & 88.5 & 100.0 & 100.0 & 86.2 & 70.0 & 61.9 & 84.4 & 84.6 \\
\hline & $\begin{array}{l}\text { Farmer's } \\
\text { practice }\end{array}$ & 8.0 & $\begin{array}{l}3.0^{b} \\
(1.9)\end{array}$ & $\begin{array}{l}1.4^{b} \\
(1.4)\end{array}$ & $\begin{array}{l}0.9^{b} \\
(1.2)\end{array}$ & $\begin{array}{l}2.6^{b} \\
(1.8)\end{array}$ & $\begin{array}{l}5.9^{b} \\
(2.5)\end{array}$ & $\begin{array}{l}8.9^{b} \\
(3.0)\end{array}$ & 3.7 & 26.6 & 76.9 & 86.8 & 92.4 & 72.3 & 41.4 & 18.4 & 64.7 & 61.1 \\
\hline & $\begin{array}{l}\text { Untreated } \\
\text { control }\end{array}$ & 12.0 & $\begin{array}{l}11.1^{\mathrm{c}} \\
(3.4)\end{array}$ & $\begin{array}{l}10.9^{\mathrm{c}} \\
(3.4)\end{array}$ & $\begin{array}{l}11.3^{\mathrm{c}} \\
(3.4)\end{array}$ & $\begin{array}{l}9.3^{\mathrm{c}} \\
(3.1)\end{array}$ & $\begin{array}{l}10.0^{\mathrm{c}} \\
(3.2)\end{array}$ & $\begin{array}{l}10.9^{\mathrm{c}} \\
(3.4)\end{array}$ & 10.6 & 68.3 & - & - & - & - & - & - & - & - \\
\hline & S. Ed & - & 0.4 & 0.07 & 0.07 & 0.43 & 0.56 & 0.52 & - & - & - & - & - & - & - & - & - & - \\
\hline & $\mathrm{CD}(\mathrm{P}=0.05)$ & $\mathrm{NS}$ & 0.95 & 0.14 & 0.17 & 0.94 & 1.22 & 1.13 & - & - & - & - & - & - & - & - & - & - \\
\hline
\end{tabular}

PTC - Pre treatment count; DAT - Days after treatment; *Mean of 7 replications; NS-Non significant

In a column, means followed by common letter(s) are not significantly different by LSD; Figures in parenthesis are square root transformed values 
Table.5 Effect of different pest management practices on natural enemies in cocoa ecosystem during 2014-2015

\begin{tabular}{|l|l|l|l|l|}
\hline \multirow{2}{*}{ Treatments } & \multicolumn{5}{|l|}{ Number of natural enemies recorded / tree at 21 DAT } \\
\cline { 2 - 5 } & $\begin{array}{l}\text { Cryptolaemus } \\
\text { montrouzieri (Grubs) }\end{array}$ & $\begin{array}{l}\text { Spalgis epeus } \\
\text { (Larvae) }\end{array}$ & $\begin{array}{l}\text { Syrphids } \\
\text { (Maggots) }\end{array}$ & Spiders \\
\hline \multirow{2}{*}{ IPM Module } & $5.7^{\mathrm{b}}$ & $\begin{array}{l}4.1^{\mathrm{b}} \\
(2.1)\end{array}$ & $\begin{array}{l}2.1^{\mathrm{b}} \\
(1.6)\end{array}$ & $1.7^{\mathrm{b}}$ \\
& $(2.5)$ & $0.5^{\mathrm{c}}$ & $0.0^{\mathrm{c}}$ & $0.8^{\mathrm{c}}$ \\
\hline \multirow{2}{*}{ Farmer's practice } & $1.2^{\mathrm{c}}$ & $(1.0)$ & $(0.7)$ & $(1.1)$ \\
\hline \multirow{2}{*}{ Untreated control } & $(1.3)$ & $9.6^{\mathrm{a}}$ & $6.3^{\mathrm{a}}$ & $5.0^{\mathrm{a}}$ \\
& $11.3^{\mathrm{a}}$ & $(3.2)$ & $(2.6)$ & $(2.4)$ \\
\hline $\mathrm{S} . \mathrm{Ed}$ & $(3.4)$ & 0.09 & 0.10 & 0.11 \\
\hline CD $(\mathrm{P}=0.05)$ & 0.10 & 0.19 & 0.21 & 0.22 \\
\hline
\end{tabular}

DAT - Days after treatment; *Mean of 10 observations; In a column, means followed by common letter(s) are not significantly different by LSD; Figures in parenthesis are square root transformed values

Table.6 Effect of different pest management practices on pod and bean yield parameters of cocoa during 2014-2015

\begin{tabular}{|c|c|c|c|c|c|c|c|c|}
\hline \multirow[b]{2}{*}{ Treatments } & \multirow{2}{*}{$\begin{array}{c}\text { Number of } \\
\text { harvestable } \\
\text { pods / tree / } \\
\text { season }\end{array}$} & \multicolumn{7}{|c|}{ Pod and bean yield parameters (Mean of 8 harvests)* } \\
\hline & & $\begin{array}{l}\text { Pod length } \\
\quad(\mathrm{cm})\end{array}$ & $\begin{array}{l}\text { Pod girth } \\
(\mathrm{cm})\end{array}$ & $\begin{array}{c}\text { Pod weight } \\
\text { (g) }\end{array}$ & $\begin{array}{c}\text { Number of } \\
\text { beans / } \\
\text { pod }\end{array}$ & $\begin{array}{c}\text { Wet bean } \\
\text { weight / pod } \\
\text { (g) }\end{array}$ & $\begin{array}{c}\text { Dry bean } \\
\text { weight / } \\
\operatorname{pod}(g)\end{array}$ & $\begin{array}{c}\text { Dry bean } \\
\text { yield/tree/season } \\
\text { (g) }\end{array}$ \\
\hline IPM module & $\begin{array}{l}28.6^{\mathrm{a}} \\
(5.4)\end{array}$ & $\begin{array}{l}18.5^{\mathrm{a}} \\
(4.4)\end{array}$ & $\begin{array}{l}26.6^{\mathrm{a}} \\
(5.2)\end{array}$ & $\begin{array}{l}588.8^{\mathrm{a}} \\
(24.3)\end{array}$ & $\begin{array}{l}37.9^{\mathrm{a}} \\
(6.2)\end{array}$ & $\begin{array}{l}126.0^{\mathrm{a}} \\
(11.2)\end{array}$ & $\begin{array}{c}39.4^{\mathrm{a}} \\
(6.31)\end{array}$ & 984 \\
\hline $\begin{array}{l}\text { Farmer's } \\
\text { practice }\end{array}$ & $\begin{array}{l}23.9^{b} \\
(4.9)\end{array}$ & $\begin{array}{l}17.2^{b} \\
(4.2)\end{array}$ & $\begin{array}{l}23.6^{b} \\
(4.9)\end{array}$ & $\begin{array}{l}482.9^{b} \\
(22.0)\end{array}$ & $\begin{array}{l}34.0^{b} \\
(5.9)\end{array}$ & $\begin{array}{l}109.7^{b} \\
(10.5)\end{array}$ & $\begin{array}{l}35.1^{b} \\
(5.9)\end{array}$ & 782 \\
\hline $\begin{array}{l}\text { Untreated } \\
\text { control }\end{array}$ & $\begin{array}{l}14.9^{c} \\
(3.9)\end{array}$ & $\begin{array}{l}15.1^{\mathrm{c}} \\
(3.9)\end{array}$ & $\begin{array}{l}20.6^{\mathrm{c}} \\
(4.6)\end{array}$ & $\begin{array}{l}371.5^{\mathrm{c}} \\
(19.3)\end{array}$ & $\begin{array}{l}28.4^{\mathrm{c}} \\
(5.4)\end{array}$ & $\begin{array}{l}92.4^{\mathrm{c}} \\
(9.6)\end{array}$ & $\begin{array}{l}27.3^{\mathrm{c}} \\
(5.3)\end{array}$ & 433 \\
\hline S. Ed & 0.76 & 0.36 & 0.57 & 1.25 & 0.61 & 1.46 & 0.73 & - \\
\hline $\begin{array}{l}\mathrm{CD} \\
(\mathrm{P}=0.05)\end{array}$ & 1.66 & 0.79 & 1.23 & 2.73 & 1.32 & 3.19 & 1.59 & - \\
\hline
\end{tabular}

*Mean of 7 replications; In a column, means followed by common letter(s) are not significantly different by LSD; Figures in the parenthesis are square root transformed values 
Rao et al., (2008) reported that neem products were safer to the natural enemies, pollinators and other non-target organisms in chickpea when compared to conventional insecticides.

\section{Effect of IPM strategy on pod yield parameters}

Results revealed that the highest number of pods were recorded in IPM plot (28.6), followed by farmer's practice (23.9) as against the lowest number of 14.9 pods in untreated control (Table 6). According to Ayenor et al., (2007) 13,100 $\pm 268,13,296 \pm 275$ and $10,500 \pm 714$ pods per hectare were recorded in neem extract, biological control agents and sex pheromones treated plots, respectively. The maximum pod length of $18.5 \mathrm{~cm}$ was recorded in the pods harvested from IPM plot followed by farmer's practice $(17.2 \mathrm{~cm})$ compared to the untreated control. Similarly, maximum pod girth of $26.6 \mathrm{~cm}$ was recorded in IPM plot and was statistically larger than the other treatments (Table 6). Regarding mean pod weight, the highest was $588.8 \mathrm{~g}$ in IPM plot followed by farmer's practice (482.9 g) and untreated control (371.5 g). The results are in line with the findings of Gopikrishna (2014) who studied the effect of different pollinator breeding substrates on the yield of cocoa.

\section{Effect of IPM strategy on bean yield parameters}

Results revealed that the highest number of beans was recorded in pods obtained from IPM plot (37.9) followed by farmer's practice (34) and untreated control (28.4). Similarly, among the treatments, weight of wet beans per pod harvested from IPM plot was recorded to be the maximum (126 g) followed by farmer's practice $(109.7 \mathrm{~g})$ and untreated control (92.4 g). The highest dry bean weight of $39.42 \mathrm{~g}$ was recorded in the IPM plot followed by farmers practice $(35.14 \mathrm{~g})$ as against the minimum dry bean weight $27.28 \mathrm{~g}$ in untreated control. The highest dry bean yield of $984 \mathrm{~g}$ per tree per season was recorded in IPM plot, followed by farmer's plot (782 g) as against the lowest dry bean yield of $433 \mathrm{~g}$ in untreated control (Table 6). Dormon et al., (2007) observed huge gap in the yield of cocoa in integrated pest management plot, farmer-adopted-IPM plot and farmers' practice with the yield of 44.6 24.9 and 19.4 $\mathrm{kg}$ per 30 trees, respectively. Gopikrishana (2014) has reported that the highest number of beans (41.2), wet bean weight (141.4 g), dry bean weight $(44.1 \mathrm{~g})$ and dry bean yield per tree per season (1072 g) were recorded in the plots where banana pseudo stem was used as pollinator breeding substrate.

Gopikrishna (2014) reported that in India, pollination in cocoa is effected only by tiny ceratopogonid and cecidomyiid midges. Safe plant protection options in cocoa plantation are vital lest it may affect the pollinators while carrying out mandatory plant protection practices. The author also reported that most of the chemical insecticides used in the cocoa ecosystem for the management of insect pests of cocoa were highly toxic to cocoa pollinators. Hence, the IPM strategy developed from this study was adjudged as the most effective treatment against the sucking insect pest complex of cocoa in terms of reducing the sucking pest load and damage, protecting the pollinators and natural enemies, increasing the pod and bean yield parameters and in turn help to increase the productivity of cocoa in India.

In conclusion, based on the results the IPM strategy was the most effective treatment against the sucking insect pest complex of cocoa. Thus the adoption of the IPM strategy is recommended not only to increase the productivity of cocoa by reducing the damage due to sucking pests, but also to conserve the natural enemies and pollinators in the cocoa ecosystem. 


\section{Acknowledgement}

The authors are grateful to Mondelez Foods India Private Limited for providing financial support in the form of junior research fellowship to the first author for carrying out the research.

\section{References}

Ayenorm, G.K., Van Huis, A., Obeng-Ofori, D., Padi, B and Roling, N.G. 2007. Facilitating the use of alternative capsids control methods towards sustainable production of organic cocoa in Ghana. Int. J. Trop. Insect Sci., 27: 85-94.

Dormon, E.N.A., Van-Huis, A and Leeuwis, C. 2007. Effectiveness and profitability of integrated pest management for improving yield on small holder cocoa farms in Ghana. Int. J. Trop. Insect Sci., 27, 27-39.

Dutta, P., Reddy, S.G.E and Borthakur, B.K. 2013. Effect of neem kernal aqueous extract (NKAE) in tea mosquito bug, Helopeltis theivora (Waterhouse, 1886) (Heteroptera: Miridae). Mun. Ent. Zool., 8, 213-218.

Gockowski, J and Sonwa, D. 2008. Biodiversity and smallholder cocoa production systems in West Africa STCP working paper series 6 (Version January 2008). International Institute of Tropical Agriculture, Accra, Ghana.

Gomez, R.A. and Gomez A.A. 1984. Statistical Procedures for Agri. Res., Wiley International Science Publication, John Wiley and Sons, New Delhi., 1984, $680 \mathrm{p}$.

Gopikrishna, K. 2014. Studies on insect pollinators of the cocoa, Theobroma cacao
(Linnaeus). M.Sc., (Ag.) Thesis, Tamil Nadu Agricultural University, Coimbatore-3, 103p.

ICO. 2014. Quarterly bulletin of cocoa statistics (International Cocoa Organisation). 33p.

Indian Horticulture Database. 2014.

Kumar, S. and Krishnanaik. 2002. Seasonal abundance of Helopeltis antonii Signoret (Heteroptera: Miridae) on guava. Karnataka J. Agric. Sci. 15, 530-533.

Prasannakumari, S., Vikraman Nair, R., Lalithabai, E.K., Mallika, V.K., Manimol, J.S., Abraham, K and Savithri, K.E. 2012. Cocoa in India. Kerala Agricultural University, Directorate of Extension, Mannuthy, Thrissur. 37-38 pp.

Rao, G.V.R, Visalakshmi, V., Suganthy, M., Vasudeva Reddy, P., Reddy, Y.V.R and Rameshwar Rao, V. 2008. Relative toxicity of neem to natural enemies associated with the chickpea ecosystem: A case study. Int. J. Trop. Insect Sci., 27, 229-235.

Sakthivel, N. and Qadri, S.M.H. 2010. Impact of insecticides and botanicals on population build-up of predatory coccinellids in mulberry, J. Biopesticides, 3, 85-87.

Uwagboe, E.O., Akinbile, L.A and Oduwole, O.O. 2012. Socio-economic factors and integrated pest management utilization among cocoa farmers in Edo state. Academic J. Plant Sci., 5, 7-11.

Wandji, N., Lapbin, N.J., Gockowski, J and Tchouamo, I. 2006. Socio-economic impact of a cocoa integrated crop pest management diffusion knowledge through a farmer field school approach in Southern Cameroon. In: Proceedings of international association of agricultural economists conference. 12-18, August, Gold Coast, Australia.

\section{How to cite this article:}

Srinivasnaik, S., M. Suganthy, S. Mohan Kumar and Jegadeeswari, V. 2017. Development and Evaluation of Integrated Pest Management Strategy against Sucking Pest Complex of Cocoa, Theobroma cacao L. Int.J.Curr.Microbiol.App.Sci. 6(2): 859-867. doi: http://dx.doi.org/10.20546/ijcmas.2017.602.096 